\title{
Civil-Military Coordination in Peacebuilding: The Obstacle in Somalia
}

\author{
Chukwuma Obinwa \\ University of Minho Portugal, chukwumaobinwa@yahoo.com
}

\begin{abstract}
The complex nature of peacebuilding as an instrument of conflict resolution has increasingly collided the military and the civilian actors to share the same field of operation, thereby undermining the independence, impartiality and neutrality of either the military or the civilian actors. Despite the fact the military has often accentuated the need for "correspondence", the civilian actors have conveyed concern regarding the effect of civil-military coordination on the capacity to remain independent, neutral and impartial in undertaking their main functions. This paper examines the cultural, organizational, operational and normative factors that condition the approaches of the civilian actors such as nongovernmental organizations and the military actors toward the civil-military coordination. This paper also discusses the obstacles to the (CIMIC) and offers more effective recommendations for enhancing the civil-military coordination (CIMIC) in order to achieve the economic, political and security order sought in the Somalia peacebuilding process.
\end{abstract}

KEYWORDS: Peacebuilding, Peace operation, Coordination, Obstacle, and Somalia

\section{Introduction}

Following the extraordinary, complex, and deteriorating situation which was causing the high magnitude of the civilian tragedy in Somalia, the United Nations (UNs) established a peacebuilding approach incorporating military and humanitarian actors into stages of activities aimed at restoring peace and security in Somali. This entails the coordination of the civilian and the military actors to work together in the same field and at the same time than the previous interventions. Civil-military coordination is particularly essential to the peacebuilding objective of managing conflict, saving lives, reducing suffering and improving livelihood (Guttieri 2004). However, in Somalia, the civil-military approach has always been problematic lacing relationship with high extent of confusion over their functions and identity (Pugh 2001). This paper examines the cultural organizational, operational and normative factors that condition the approaches of the civilian and military actors in the peacebuilding process in Somalia. While the paper discusses the evolution of the peacebuilding process in Somalia, the main focus of the paper is to examine the obstacles facing the CIMIC in Somalia and to consider a more effective recommendation for better coordination of the civil and military actors in Somalia. The first section of this paper discusses the evolution of peacebuilding in Somalia and the concept of civilmilitary coordination. The second section discusses the normative, operational, cultural and organizational differences that hinder the civilian and military actors in the peacebuilding process in Somalia. The final section offers recommendations for how to enhance civilian and military coordination and to improve the effectiveness of the peacebuilding efforts in Somalia. This study is a product of an analysis of academic literature on civil-military coordination.

\section{Evolution of Peacebuilding in Somalia}

During the Cold War era, traditional peacekeeping under chapter VI of the United Nations charter was authorized. This most predominantly integrated "imposition of neutral and lightly armed intervention troops following the cessation of armed conflict, and with the intervention and the permission of the host state where the troops are deployed to prevent the recurrence of the armed conflict, and create the atmosphere under which the underlying conflict can be addressed" (Goulding 2003; Diehl 1993; Bellamy et al. 2004). The fast rise in the ethnic strife and civil wars after the end of the Cold War and the urgent need for actions to assist the civilian populations subjected to ethnic massacre indicated the obligation of the international community to act above peacekeeping and to authorize peace enforcement mission under the chapter V11 of the United Nations charter in order to impose compliance with the international sanctions and resolutions and to "restore and maintain peace and 
support diplomatic process in order to achieve a long-term political settlement" (Dept. of the Army 1994).

At the beginning of the 1990s, it was clear that the humanitarian crises were intrinsically related to peace and security problems. In the regard, United Nations Security Council Resolution 794 (UNSCR Somalia 1992), for the first time, under chapter VII of the charter of the UN authorized military intervention in Somalia in order to create a safe and secure environment for humanitarian relief activities. Following the extraordinary, complex, and deteriorating situation which was causing the high magnitude of the civilian tragedy in Somalia, the UNs established a peacebuilding approach incorporating military and humanitarian actors into stages of activities aimed at restoring peace and security in Somalia by helping in humanitarian assistance, observing ceasefire and settlement of refugees in order to contribute to the social reconciliation, economic reconstruction and rehabilitation of the vital government functions (Boutros-Ghali 1995; Jeong et al. 2006). It is in the addressing of the security challenges in Somalia that the active alliance between military and civilian humanitarian actors become necessary but on the contrary, it is also that the main strains between the military forces and civilian peacebuilding components emanate. Since the extraordinary nature of the security situation in Somalia called for the amalgamation of conventional peacekeeping roles such as observation of ceasefire, demobilization, disarmament, and supervision of elections and peace enforcement operations, peacebuilding activities always alluded to as $3^{\text {rd }}$ generational peace missions that closely look like peacekeeping missions, but with the addition of something new giving that the peacebuilders contribute to rehabilitating of the worn torn state and the social structures.

\section{Civil-Military Coordination}

The term 'civil-military coordination' is widely taken to involve a broad range of issues spanning from control and command (the issues of political/civilian control of the military apparatus) to all forms of interplay between the military and the larger society (Lilly 2002). However, for the aim of this paper, a more limited issue is examined. The interplay between international armed forces and the humanitarian civilian sharing the field during peace operations.

According to (Mockaitis 2004), civil-military coordination involves three major tasks such as "liaison between the military contingent and all the civilian player in the field of operation, military support to the civilian environment and the civilian support to the armed troops in the peace operation." For (Holshek and Coning 2017), civil-military coordination is intrinsically strategic effort that, despite the doctrinal modus operandi, is necessarily about managing interplays among different actors involved in the peace operation and controlling the metamorphosis from conflict to peace. Also, civil-military coordination is the interface and dialogue among military, police and civilian component of peace mission regarding the humanitarian, security, political, developmental, and other dimensions of the mission. This interface and dialogue can assist to achieve larger political objectives related to peacemaking, peacekeeping, conflict prevention, peace enforcement, peacebuilding and humanitarian relief in a peripheral zone. Civil-military coordination is the dialogue between humanitarian groups and the military actors for the humanitarian objectives. In a wider term, 'civil-military co-ordination' generally refers to the interplay between the military actors and a broader range of civilian actors involving civil society, development and human rights actors for military purposes (Metcalfe et al. 2012).

The international organizations and United Nations have avoided using the terminology 'Civil-Military Cooperation (CIMIC)' focusing on 'co-ordination' instead of 'cooperation'. For the United Nations Department of Peacekeeping Operation (UN DPKO), civil-military coordination is referred as a system of interplay involving exchange and sharing of information, negotiation, mutual support, de-confliction and planning at all stages between military components, the civilian population and humanitarian organization to actualize respective goals (UN DPKO 2002). According to the Inter-Agency Standing Committee (IASC) the main instrument for the coordination of the humanitarian relief, Civil-Military Coordination (CM Cood) is, 
"the essential dialogue and interaction between civilian and military actors in humanitarian emergencies that are necessary to protect and promote humanitarian principles, avoid competition, minimize inconsistency and when appropriate pursue common goals (IASC 2004, 5)".

The dispute in terminology represents the defensive and cautious behavior to civil-military co-operation amongst civilian actors as a result of the domineering behavior of the military actors who are authorized by their political leaders in the government (Gourlay 2003). The important factor concerning civilmilitary relations regardless of the title is to ensure that this interaction is coherent and complementary with clear objectives and tasks without undermining the presence or the relevance of the other (Gourlay 2003).

\section{The Obstacle}

Perceiving the potential of CIMIC for undermining the independence, impartiality and neutrality of NGOs and humanitarian agencies, the ICRC started in the early 1990s to campaign the concept of "Humanitarian space" which interprets the capacity of humanitarian organizations to act independently, impartially and neutrally in the absence of fear of threat in quest of the humanitarian imperative. This entails that the humanitarian actors will be to free help the population in need, and they are not constrained by physical or political obstacles to their task (Sida 2005, see Roggo 2002). Theoretically, the military at least becomes engaged in the humanitarian missions only in a very serious situation when the people are at risk or dying, and only the military can protect them (Sida 2005). Practically, however, the civilian actors are particularly worried about the military actors performing relief tasks as part of their approach to "capture the hearts" of the local population. The military "heart strategy" can easily cause confusion in the role of the civilian actors and the military actors in the same field of operation.

This obstacle as observed by Sedra (2004) is that while the military demonstrates the importance of "complementarity" with the civilian actors, the civilian actors have become wary of its effects on their capacity to remain independent, impartial and neutral. As peacebuilding acquires operational relevance, an increasing number of military commanders appear to accept the military actor's growing double responsibilities; to operate as an armed force and to support humanitarian relief (Rana 2004). Civilian actors operating in a hostile peripheral zone need the military for logistics and security while the military actors need those civilian actors to handle the humanitarian relief (Guttieri 2004) However, in spite of the increasing acceptance of the widening military operation obligations, obstacles persist in the civilian-military coordination effort and this has continuously impeded the effectiveness of peacebuilding.

\section{Cultural Difference}

Different cultures have exerted a significant effect on the level of civil-military coordination, an obstacle which has been demonstrated by the previous and the current civilian personnel and by the military personnel in Somalia. In general, (Minear et al. 2000) argued that the military personnel is trained, equipped to use regulated and organize violence to accomplish their mandates. The military places a high priority on command and control, well defined lines of accountability, discipline and authority and prioritized logistics. On the contrary, the civilian agencies are decentralized and place a high value on the process. The civilian personnel perceives themselves as a peaceful individual who has committed their lives to help those people devasted by war while the military actors in most cases are troops trained for war. The military actors see the civilian personnel as peace activists thereby they underrate their relevance in the peacebuilding process. This has been demonstrated by the military actors through arrogance, chauvinistic behaviors, and the dismissal of opinions and information provided by the civilian workers. This disrespect for the civilian workers can easily damage the already weak level of coordination existing on the field of operation. These cultural differences do not contribute only to disagreeing mutual expectations, but most the times, to negative thoughts that members of these groups have for each other (Beauregaid 1998). For example, in Somalia, the military anticipated the civilian 
actors to support its objectives of law enforcement while the civilian actors expected the military to complement their efforts in aid delivery (Jeong 2005).

\section{Organizational and Operational Difference}

The Organizational structures of the military component and the civilian agencies are commonly polar opposites. Military forces are state servants deployed by government, this makes the military command structure a vertical and centralized with a clear line of authority moving hierarchically from top to bottom. Decisions clearly involve defining deadline and operations specific rules of engagement from the commander of the armed force to the soldiers on the ground (Rubinstein 2003; Pugh 2001). In Somalia, the military and police personnel are guided by AMISOM commander. On the contrary, the organizational structure of the civilian agencies is more diffused and horizontal which is based on consensus-approach allowing for substantial decision created in the field by the civilian workers (Jeong 2005). The civilian actors are guided by international standard and humanitarian principles. These varying organizational structures have become an obstacle to effective coordination on several grounds. For instance, because the civilian personnel and military personnel are not familiar with the other's pattern of structures, they encounter an obstacle in setting up congruent communication link and suitable decision making.

\section{Normative Difference}

According to the International Committee of Red Cross (ICRC), "measures are humanitarian if they meet the principles of independence, impartiality and neutrality. Relief measures that fail to follow these measures are not humanitarian, despite their effectiveness and benevolent intentions (VERNO Position Paper 2003). In practice, humanitarian assistance ought to reach all the people affected by war and it is targeted at reducing human suffering and at saving lives. As such, humanitarian assistance must be independent of the military, political, economic and other goals held by any actor regarding the areas where humanitarian activity is being implemented. It must be administered impartially without discrimination on the basis of gender, race, ethnicity, nationality or political orientations. It also must be neutrally provided without taking a side in any religious or political controversies (Somalia CountrySpecific Civil-Military Coordination Guidelines Draft-Version 2014), By the contrary, the military is established to pursue a national political interest and to accomplish the objectives of the through the use of force. In Somalia, the coercive intervention of the military forced the civilian workers to seek protection of the peacekeepers or the local armed group. This protection may enhance the physical access to the conflict areas and protect populations, but this may compromise the humanitarian principles of independence, impartiality and neutrality when the civilian actors are associated with the military.

\section{Conclusion and Recommendations}

The above concise description shows that the relationship between the military and the civilian aid agencies is not a smooth one. Their cultural, organizational, operational and normative structures are incompatible. However, it is acceptable that peace and stability cannot be achieved through military instrument alone. The non-military instrument is deployed to support the stabilization process, and the civilian aid workers increase the operation legitimacy and boost the morale of the troops.

Effective civil-military coordination can be achieved by organizing high quality training and seminars with emphasis on discipline which can yield unity of efforts without undermining the importance of either the military on the civilian agencies in the field.

Effective leadership from both humanitarian agencies and AMISOM is essential to ensure a good relationship in the field of operation.

There is a need for a clear distinction between the roles, identities, mandates and functions of the military and the civilian on the basis of comparative advantages. The AMISOM should focus on peace and stabilization efforts while the civilian works should embark of humanitarian aid delivery. 
There is a need to set up a task force or committee with the primary role of ensuring and maintain consistent and coherent civil-military coordination. Actors at all times should maintain a distinct and appropriate dress that clearly shows either civilian or military status.

The civilian workers should avoid undertaking joint operations or evaluation with AMISOM and the use of AMISOM facilities. Such practices could cause a negative perception of civilian workers as impartial actors in Somalia.

Finally, information sharing between civilian agencies and military workers should have a clear goal of improving mutual understanding of the mandates and roles. Information that might compromise the neutrality and impartiality of either actor should not be shared.

\section{References}

Beauregard, A. 1998. "Civil (NGO) - Military Cooperation: Lessons from Somalia, the Former Yugoslavia and Rwanda." The Ploughshares Monitor 19(4). Retrieved March.

Bellamy, A. J., Williams, P. D., \& Griffin, S. 2004. Understanding peacekeeping. Cambridge, UK: Polity Press.

Boutros-Ghali, Boutros 1995. An Agenda for Peace 1995. By. 2d ed. New York: United Nations.

Department of The Army Washington Dc. 1994. "Peace Operations.” Doi:10.21236/ada298934.

Goulding, M. 2003. Peacemonger. Baltimore, MD: Johns Hopkins University Press.

Gourlay, C. 2000. "Partners Apart: Managing Civil-Military Co-operation in Humanitarian Interventions." Disarment Forum.

Guttieri, K. 2004. “Civil-military relations in peacebuilding.” Sicherheit \& Frieden 22(2): 79-85. Doi:10.5771/0175274x-2004-2-79.

Holshek, C., \& Coning, C. 2017. “Civil-Military Coordination in Peace Operations.” Peace Operations Training Institute. Doi:10.4324/9780203876237.

Inter-Agency Standing Committe (IASC). 2004. Civil Military Relationship in Complex Emergencies.

Jeong, H., Talentino, A. K., Covey, J., Dziedzic, M., \& Hawley, L. 2006. "Peacebuilding in Postconflict Societies: Strategy and Process." Foreign Affairs 85(1): 150. Doi:10.2307/20031863.

Lilly, D. 2002. "The Peacebuilding eacebuilding Dimension of Civil-Military Dimension in Complex Emergencies.” International Alert. Doi:10.1515/9781400861422.93.

Metcalfe, V., Haysom, S., \& Stuart Gordon, S. 2012. Trends and challenges in humanitarian civil-military coordination A review of the literature. London: Humanitarian Policy Group Overseas Development Institute.

Minear, Larry, Sommers, M., \& Baarda, T. V. 2000. "NATO and Humanitarian Action in the Kosovo Crisis." Occasional Paper \#36, Thomas J. Watson Institute of International Studies, Brown University.

Mockaitis, T. R. 2004. "Civil-Military Cooperation in Peace Operations: The Case of Kosovo." Doi:10.21236/ada427679.

Pugh, M. 2001. "The Challenge of Civil-military Relations in International Peace Operations.” Disasters 25(4): $345-$ 357. Doi:10.1111/1467-7717.00183.

Rana, R. 2004. "Contemporary challenges in the civil-military relationship: Complementarity or incompatibility?" Revue Internationale De La Croix-Rouge/International Review of the Red Cross 86(855): 565. Doi:10.1017/s1560775500181040.

Roggo, M. 2000. “After the Kosovo Conflict, a Genuine Humanitarian Space: A Utopian Concept or an Essential Requirement? International Review of the Red Cross 8: 837th ser.

Rubinstein, R. A. 2003. “Cross-Cultural Considerations in Complex Peace Operations.” Negotiation Journal 19(1): 2949. Doi:10.1111/j.1571-9979.2003. tb00278.x.

Sedra, M. 2004. "Civil-Military Relations in Afghanistan: The Provincial Reconstruction Team Debate." Asia-Pacific Foundation of Canada Research Paper.

Sida, L. 2005. "Challenges to Humanitarian Space: A Review of Humanitarian Issues related to the UN integrated Mission in Liberia and to the Relationship between Humanitarian and Military Actors in Liberia." Study for the Humanitarian Information Center.

Somalia Country Specific Humanitarian Civil-Military Coordination Guidelines for Humanitarian Actors Engagement with the African Union Mission in Somalia (AMISOM) [Review]. 2014, November 24. Somalia CountrySpecific Civil Military Coordination Guidelines - Draft Version.

United Nations Department of Pea United Nations Department of Peacekeeping Operations (UN DPKO). 2002. Civil military coordination policy. New York: United Nations.

United Nations Security Council Resolution 794. 1992. UNSCR Somalia. Adopted by the Security Council at its 3145th meeting, on 3 December 1992.

VERNO. 2003. VERNO Position Paper. Armed Forces as Humanitarian Aid Workers? Scope and Limits of CoOperation between Aid Organisations and Armed Forces in Humanitarian Aid, May 2003. 